\title{
Karakteristik Morfologi Kampung Kota Gandek Puspo Kelurahan Jagalan Semarang
}

\section{Morphological Characteristics Of Kampung Kota Gandek Puspo Jagalan Semarang}

\author{
Made Ria Anggrini Rustika ${ }^{a}$ dan Nurini ${ }^{\mathrm{b}}$ \\ ${ }^{a b}$ Universitas Diponegoro, Kota Semarang, Indonesia
}

\begin{abstract}
Abstrak
Kemunculan kampung kota di Kota Semarang dimulai sejak masa kolonial Belanda, salah satunya adalah Kampung Kota Pribumi (penduduk asli Kota Semarang). Kampung Gandekan; Kampung Kulitan; Kampung Banginggris; dan Kampung Pusporagan dikenal dengan sebutan Kampung Gandek Puspo merupakan Kampung Kota Pribumi yang memiliki nilai historikal. Kampung tersebut menjadi pusat kejayaan Tuan Tasripin sebagai Tuan Tanah di Kota Semarang, hal ini ditandai dengan berbagai peninggalan tempo dulu yang masih terjaga hingga saat ini. Kampung Gandek Puspo telah mengalami perkembangan (fisik dan non fisik) yang mempengaruhi karakteristik morfologi kawasan. Penelitian ini dilakukan untuk mengetahui karakteristik morfologi Kampung Kota Gandek Puspo, metode penelitian yang digunakan adalah metode kualitatif deskriptif, dengan teknik pengumpulan data observasi dan wawancara. Data hasil wawancara akan diolah melalui pengkodean data, kategorisasi, dan reduksi data, kemudian dianalisis menggunakan teknik analisis deksriptif, analisis morfologi dengan pendekatan teori Urban Design, dan analisis spasial (peta komik). Hasil penelitian menunjukkan bahwa terdapat dua karakteristik morfologi Kampung Gandek Puspo yaitu kampung bagian depan (sebagian Kampung Gandekan dan sebagian Kampung Kulitan yang berada dekat Jl. MT. Haryono), dan kampung bagian belakang (Kampung Banginggris; Kampung Pusporagan; sebagian Kampung Gandekan; dan sebagian Kampung Kulitan; yang berada dekat sungai Semarang).
\end{abstract}

Kata kunci: Kampung Kota; Morfologi Kota; Kampung Gandek Puspo

\begin{abstract}
The emergence of urban villages in the city of Semarang began in the Dutch colonial period, one of which is Kampong Kota Pribumi (a native of Semarang City). Kampong Gandekan; Kampong Kulitan; Kampong Banginggris; and Kampong Pusporagan known as Kampong Gandek Puspo is an Indigenous Town Kampong which has historical value. The Kampong became the center of Tuan Tasripin's triumph as a landlord in the city of Semarang, this is marked by various relics of the past that are still preserved today. Kampong Gandek Puspo has experienced developments (physical and non-physical) which affect the morphological characteristics of the area. This research was conducted to determine the morphological characteristics of the Kampong Kota Gandek Puspo. The research method used was descriptive qualitative method, with observation and interview data collection techniques. The interview data will be processed through data coding, categorization, and data reduction, then analyzed using descriptive analysis techniques, morphological analysis using the Urban Design theory approach, and spatial analysis (comic maps). The results showed that there were two morphological characteristics of Kampong Gandek Puspo, namely the front Kampong (part of Kampong Gandekan and part of Kampong Kulitan which is near Jl. MT. Haryono), and the rear village (Kampong Banginggris; Kampong Pusporagan; part of Kampong Gandekan; and partly Kampong Kulitan; which is near the Semarang river).
\end{abstract}

Keywords: Urban Kampung, Urban Morphology, Kampong Gandek Puspo

${ }^{a}$ Made Ria Anggrini Rustika: Universitas Diponegoro, Semarang, Indonesia

E-mail address: maderiaanggrini@gmail.com

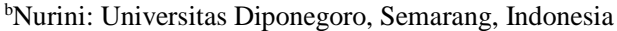

E-mail address: nur1n1@yahoo.com 


\section{Pendahuluan}

Kampung Kota yang merupakan kawasan permukiman informal, tumbuh dan berkembang tanpa adanya perencanaan dan pengendalian pembangunan, hal ini dapat dapat terlihat dari bentuk fisik ruang yang cenderung tidak tertata, serta ruang aktivitas sosial yang bersifat kebersamaan dan memiliki bentuk dan fungsi yang khas sesuai karakteristik masyarakat. Terdapat tiga jenis kampung kota di Kota Semarang berdasarkan karakteristik penduduk pada era Kolonial Belanda yaitu Kampung Kota Belanda (penduduk asal Belanda), Kampung Kota Melayu (Penduduk asal Arab, Cina, dan Melayu), dan Kampung Kota Pribumi (penduduk asli Kota Semarang). Ketiga kampung tersebut, sebagian besar berada di Kecamatan Semarang Tengah yang menjadi awal perkembangan Kota Semarang tepatnya berada di jalan Pandanaran, jalan Gajahmada, dan jalan Pemuda. Secara spasial, jalan - jalan tersebut saling berhubungan membentuk pola segitiga yang saat ini dikenal dengan sebutan "Segitiga Emas Kota Semarang". Kawasan "Segitiga Emas Kota Semarang" didominasi oleh kampung kota Belanda dan kampung kota Melayu, sedangkan kampung kota Pribumi tersebar di kawasan 'Segitiga Emas Kota Semarang" dan sekitar jalan MT. Haryono, salah satunya berada di Kelurahan Jagalan. Kelurahan Jagalan tumbuh dan berkembang dari kegiatan pemotongan hewan, dimana sebagian besar para pekerja bertempat tinggal pada kawasan disekitar tempat pemotongan hewan.

Kampung Gandekan; Kampung Kulitan; Kampung Banginggris; dan Kampung Pusporagan yang terletak di Kelurahan Jagalan, dikenal dengan sebutan Kampung Gandek Puspo. Kampung tersebut memiliki nilai sejarah tentang kejayaan Tuan Tasripin sebagai tuan tanah di Kota Semarang, ditandai dengan terdapatnya bangunan berarsitektur tempo dulu seperti bangunan rumah tempat tinggal keluarga Tasripin, masjid Al Taqwa, Mushola Gandekan, dan lain sebagainya. Kampung ini telah mengalami perkembangan sejak periode 1800-2000, baik morfologi kawasan maupun kondisi sosial-ekonomi masyarakat, khususnya di Kampung Kulitan dan Kampung Gandekan (Nurini, 2002). Eksistensi Kampung tersebut sebagai kampung kota bersejarah di Kota Semarang saat ini kurang dikenal masyarakat, bahkan beberapa bangunan berarsitektur tempo dulu telah mengalami perubahan baik fisik maupun non fisik. Bentuk kawasan (morfologi) yang berubah-ubah dipengaruhi oleh aktivitas masyarakat. Hal inilah yang menjadikan pentingnya penelitian ini dilakukan, mengingat belum adanya kajian menyeluruh terkait kondisi Kampung Kota Gandek Puspo yang meliputi Kampung Gandekan, Kampung Kulitan, Kampung Banginggris, dan Kampung Pusporagan.

Penelitian ini bertujuan untuk mengkaji dan menganalisis karakteristik morfologi kampung kota Gandek Puspo melalui pendekatan teori Urban Design, sebagai bahan pertimbangan perencanaan dan pembangunan agar sesuai dengan karakteristik yang ada, serta dapat mempertahankan karakteristik khas yang ada di kampung kota Gandek Puspo. Adapun sasaran dalam penelitian ini adalah mengidentifikasi kronologi perkembangan kawasan; mengidentifikasi karakteristik fisik dan non fisik kawasan; menganalisis karakteristik morfologi kawasan melalui pendekatan Urban Design (figure ground, linkage, and place); menganalisis hal-hal yang mempengaruhi karakteristik morfologi kawasan. Lokasi penelitian adalah Kampung Kota Gandek Puspo (Kampung Gandekan; Kampung Kulitan; Kampung Banginggris; dan Kampung Pusporagan) Kelurahan Jagalan. Luas kawasan penelitian $\pm 4 \mathrm{Ha}$, Kampung Gandekan dan Kampung Kulitan secara administrasi tergabung dalam satu RW yaitu RW 07, sedangkan Kampung Banginggris dan Kampung Pusporagan tergabung dalam satu RW yatu RW 08. 


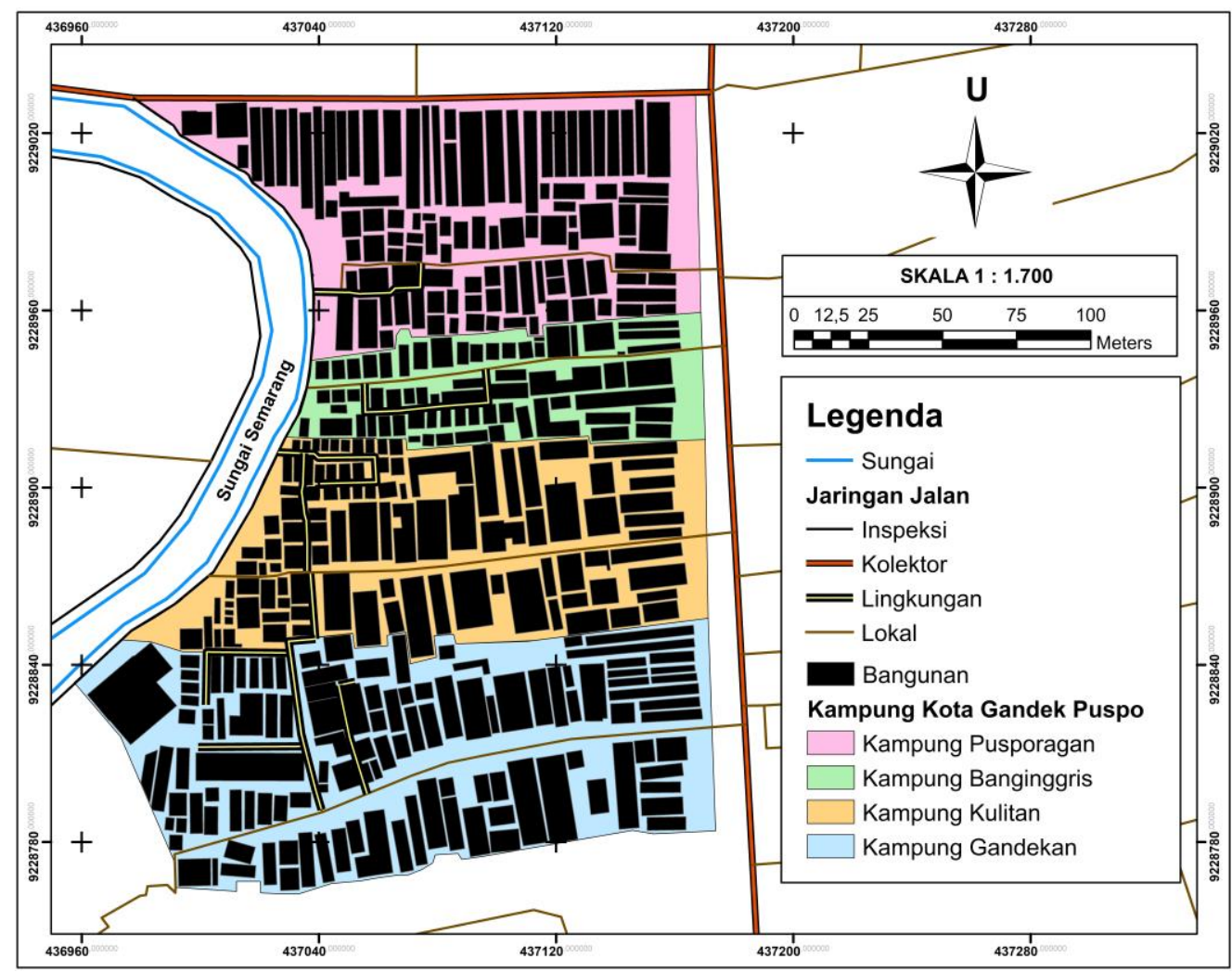

Gambar 1. Peta Kawasan Kampung Kota Gandek Puspo

\section{Metode}

Metode penelitian yang digunakan adalah kualitatif deksriptif, metode ini digunakan untuk mengkaji, menganalisis, dan menjelaskan kondisi di lokasi penelitian, yang didukung dengan teori sebagai dasar penelitian. Teknik pengumpulan data yang digunakan yaitu observasi (pengamatan langsung) dan wawancara. Teknik sampling yang digunakan untuk menentukan target narasumber adalah purposive sampling dan snowball sampling (Sugiyono, 2015). Teknik purposive sampling melibatkan penduduk asli yang mengetahui sejarah perkembangan kawasan, sedangkan teknik sampling snowball sampling melibatkan toko masyarakat/ketua RT setempat yang berjumlah 4 orang. Data hasil wawancara, kemudian diolah terlebih dahulu melalui tahapan pengkodean data, kategorisasi, dan reduksi data (penyederhanaan). Teknik analisis yang digunakan yaitu analisis deskriptif untuk menjelaskan dan menguraikan secara detail informasi dari setiap data yang telah diolah, analisis urban design digunakan untuk menjelaskan karakteristik morfologi Kampung Gandek Puspo melalui perbandingan kondisi di lokasi penelitian dengan teori-teori yang menjadi dasar penelitian meliputi theory figure ground; theory linkage; dan theory place (Zahnd, 1999), serta analisis spasial berupa analisis peta komik yang digunakan untuk menjelaskan kondisi di lokasi penelitian secara spasial berupa titik lokasi objek pengamatan yang dilengkapi dengan gambar/foto real kondisi di lapangan. Teknik analisis tersebut digunakan untuk menjawab setiap sasaran penelitian diantaranya : menjelaskan kronologi perkembangan kawasan menggunakan analisis deskriptif kualitatif; mengidentifikasi kondisi fisik (penggunaan lahan, ketersediaan sarana dan prasarana, kondisi fisik bangunan) dan non fisik (sosial-ekonomi masyarakat) kawasan menggunakan analisis deskriptif kualitatif dan analisis spasial; serta menganalisis karakteristik morfologi kawasan, dan hal-hal yang mempengaruhi karakteristik morfologi kawasan menggunakan analisis urban design, analisis deskriptif kualitatis, dan analisis spasial.

\section{Kajian literatur}

Morfologi kampung kota dapat diidentifikasi dan dianalisis menggunakan pendekatan teori urban design, meliputi teori Figure Ground, teori Linkage, dan teori Place (Zahnd, 1999). Teori Figure Ground menjelaskan bahwa pola perkotaan dapat dilihat dari hubungan antara 
bentuk yang dibangun (building mass) dan ruang terbuka (open space), meliputi tekstur dan pola tata ruang perkotaan; dan keteraturan massa/ruang meliputi pola susunan homogen, heterogen, dan menyebar. Teori Linkage, digunakan untuk menjelaskan hubungan antar ruang perkotaan dan dinamika tata ruang perkotaan, yang secara spasial akan membentuk garis-garis yang saling menghubungkan antar ruang perkotaan, dengan tiga pendekatan yaitu linkage visual, linkage structural, dan linkage kolektif. Teori Place, digunakan untuk menjelaskan bahwa ruang-ruang perkotaan terbentuk karena adanya aktivitas masyarakat, yang berlatar sosial budaya, sehingga ruang-ruang yang terbentuk memiliki makna dan unsur karateristik yang khas. Secara arsitektural, makna suatu ruang dapat dilihat dari tiga pendekatan yaitu konteks, citra, dan estetika. Menurut (Lynch, 1960), sebuah kota memiliki citra kota yang menggambarkan karakteristik dan makna dari sebuah kota seperti makna sosial, fungsi, sejarah, atau bahkan makna sebuah nama. Terdapat lima elemen citra kota yaitu path (jalur), edge (tepian), district (kawasan), node (simpul), landmark (tangeran).

Kampung kota secara morfologi merupakan ruang informal yang terbentuk secara tidak terencana, dimana ruang-ruang tersebut berisi kondisi sosial dan karakter budaya masyarakat yang masih mencirikan pedesaan (Soetomo, 2009). (Kurniasari et al., 2019) menjelaskan, penduduk kampung berasumsi bahwa gang adalah ruang yang dapat digunakan untuk aktivitas hunian. Beliau juga menjelaskan bahwa ketidaksesuaian antara kondisi tempat tinggal dengan kebutuhan penghuni yang harus dipenuhi, mengharuskan kegiatan rumah dilakukan diluar rumah seperti kegiatan memasak dan mencuci dilakukan di gang rumah. Kondisi inilah menjadi salah satu ciri permukiman kampung kota. Dominasai karakteristik bangunan rumah kampung kota adalah bangunan semi permanen dan non permanen, dengan bentuk arsitektural bergaya sederhana menengah kebawah. Namun, berbeda halnya dengan karakteristik bangunan rumah kampung kota bernilai sejarah, memiliki bentuk arsitektural yang khas. Pada era kolonial Belanda di Indonesia khususnya di Pulau Jawa, meninggalkan berbagai jejak peninggalan yang masih dipertahankan hingga saat ini, salah satunya adalah arsitektur bangunan bergaya Indis. Dalam buku yang di tulis (Soekiman, 2014), dijelaskan bahwa terdapat kebudayaan Indis yang terkenal di era kolonial Belanda. Dimana pada era colonial Belanda, bangsa Belanda tidak hanya menjadi penguasa tapi juga berpengaruh terhadap gaya hidup, bentuk bangunan rumah, dan fungsi ruang (Soekiman, 2014). Budaya Indis merupakan kebudayaan yang memadukan budaya Belanda dan budaya pribumi, terdapat beberapa ciri bangunan rumah bergaya indis diantaranya seperti bentuk atap rumah, hiasan atap rumah (petunjuk arah angin, cerobong asap, hiasan kemuncak depan), hiasan berbahan logam (lampu jalan, pagar, kursi kebun, lampu dinding, penyangga atap), hiasan tubuh bangunan rumah (lubang angin/ventilasi), pintu dan jendela rumah.

Perubahan bentuk fisik kawasan dan pola fungsional lingkungan merupakan konsekuensi untuk mengakomodasi kebutuhan ekonomi yang berubah, nilai sosial, dan kondisi infrastruktur (Ariga, 2005). Perubahan bangunan rumah penduduk akan berpengaruh terhadap morfologi kawasan. Dalam penelitian (Funo et al., 2002) dijelaskan bahwa, rumah-rumah kampung kota cenderung mengalami perubahan secara bertahap sesuai kebutuhan, perubahan tersebut dapat berupa penambahan kamar sehingga mengubah struktur bangunan, perubahan bahan bangunan rumah dari non permanen menjadi semi permanan dan permanen. Hal ini juga dijelaskan dalam penelitian (Kurniasari et al., 2019), bahwa tranformasi fisik kampung kota paling umum terlihat pada perubahan luas tempat tinggal, terdapat empat Jenis transformasi hunian kampung kota yaitu perubahan bangunan rumah, penambahan ruang hunian, perluasan hunian, dan modifikasi rumah. Selain itu, perubahan morfologi kawasan juga disebabkan karena faktor skala makro meliputi bencana alam; renovasi kawasan secara menyeluruh; perbaikan dan pembongkaran kawasan setelah perang; dan perubahan sistem jaringan jalan, serta faktor skala mikro meliputi perubahan konstruksi bangunan dan perubahan ukuran petak blok bangunan (Agirbas \& Ardaman, 2015). Perubahan fisik bangunan dapat meliputi bentuk fisik atap bangunan rumah, dinding rumah, bentuk jendela rumah, pilar-pilar bangunan rumah, dan bahan bangunan rumah (Omar. et all, 2018). Berdasarkan uraian tersebut, dapat disimpulkan bahwa hal-hal yang dapat mempengaruhi bentuk kawasan (morfologi) yaitu ketersediaan sarana dan prasaran; aktivitas sosial ekonomi; dan aktivitas hunian. 


\section{Hasil dan Pembahasan}

\subsection{Analisis Kronologi Perkembangan Kampung Kota Gandek Puspo}

Berdasarkan hasil wawancara dan telaah dokumen penelitian terdahulu Nurini (2002), dijelaskan bahwa toponim Kampung Pusporagan tercetus dari seorang Kyai Raden Mas Tumenggung Pusporogo yang datang dan bertempat di kampung ini, kemudian setelah beliau pindah kampung ini dikenal dengan sebutan Kampung Pusporagan dan menjadi tempat tinggal penduduk yang berasal dari berbagai daerah. Kampung Banginggris dahulu ditempati oleh penduduk berkembangsaan Inggris, dengan ciri khas terdapat kebun disetiap rumah, sehingga tercetuslah nama Kampung Banginggris. Kampung Kulitan, dahulu ditempati oleh Kyai Saridin dan menurunkan seorang anak bernama Tassimin Koetjeer, kemudian mulai menggeluti kegiatan pemprosesan kulit yang sukses dan kemudian diteruskan oleh anaknya bernama Tasripin, sehingga tercetuslah nama Kampung Kulitan pada daerah ini. Kampung Gandekan dahulu menjadi tempat persinggahan seorang utusan (gandek/duta) dari Mataram, sehingga tercetuslah nama Kampung Gandekan pada daerah ini. Keempat kampung tersebut menjadi cikal bakal kejayaan Tuan Tasripin sebagai tuan tanah di Kota Semarang, dahulu masyarakat menyebut kawasan tersebut sebagai Kampung Kota Gandek Puspo. Konon, Raden Mas Tumenggung Pusporogo yang dahulu datang dan bertempat tinggal di Kampung Pusporagan, menguasai daerah yang berada dibawah Kampung Pusporagan meliputi Kampung Banginggris, Kampung Kulitan, dan Kampung Gandekan, sehingga masyarakat biasa mengenal dengan sebutan Kampung Gandek Puspo. Kampung ini mulai berkembang sejak pertengahan tahun 1800an, Kampung Kulitan menjadi pusat perkembangan, khususnya menjadi pusat kegiatan pengkulitan dan tempat tinggal keluarga Tuan Tasripin. Sebagai tuan tanah, beliau kemudian membagi kaveling Kampung Gandek Puspo sesuai peruntukannya meliputi kaveling yang berukuran besar di Kampung Kulitan sebagai tempat tinggal keluarga Tuan Tasripin, kaveling berukuran besar di Kampung Gandekan diperuntukkan sebagai gudang kulit, sedangkan kaveling berukuran kecil di Kampung Banginggris dan Kampung Pusporagan menjadi tempat tinggal para pekerja/abdi Tuan Tasripin. Berdasarkan uraian diatas dapat dilihat bahwa perkembangan Kampung Gandek Puspo telah berkembang sejak tahun 1800an, dan menjadi cikal bakal kejayaan keluarga Tasripin. Pembagian fungsi kawasan dipengaruhi oleh keberaan Tuan Tasripin sebagai Tuan Tanah sekaligus pemilik usaha pengkulitan, fungsi kawasan terlihat jelas dari perbedaan ukuran kaveling, pembagian kaveling di Kampung Gandekan dan Kampung Kulitan cenderung lebih luas dibandingan kaveling di Kampung Banginggris dan Kampung Pusporagan.

\subsection{Analisis Morfologi Kampung Kota Gandek Puspo \\ 4.2.1. Figure Ground}

Secara spasial, kawasan Kampung Kota Gandek Puspo memiliki susunan pola kawasan yang bersifat homogen, yang terlihat pada pola sebaran bangunan mengikuti pola jaringan jalan yang berbentuk grid, sehingga susunan blok bangunan terkesan sama berupa blok bangunan persegi (rumah) dan persegi panjang (pertokoan). Penggunaan lahan di Kampung Gandek Puspo didominasi dengan penggunaan lahan perdagangan dan jasa, serta penggunaan lahan permukiman. Berdasarkan status kepemilikan lahan, sebagian besar lahan di Kampung Gandek Puspo berstatus belum terdaftar. Jika dilihat berdasarkan kronologi perkembangan kawasan, sebagian besar lahan Kampung Kota Gandek Puspo menjadi milik Tuan Tasripin. Namun, pada peta menjelaskan bahwa lahan dengan status kepemilikan hanya pada beberapa bangunan khususnya pada bangunan rumah peninggalan Tuan Tasripin. 


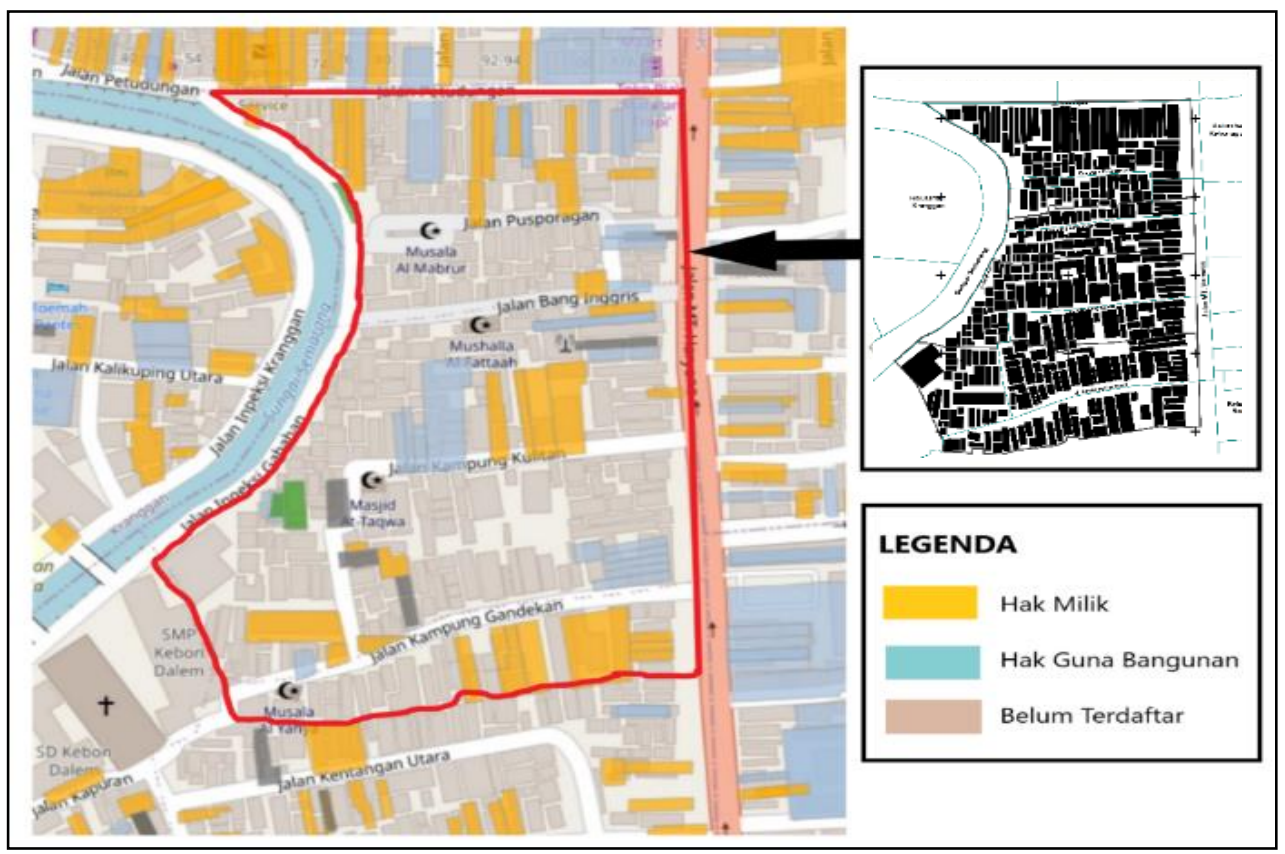

Gambar 2. Peta Sebaran Kepemilikan Lahan di Kampung Kota Gandek Puspo (Peta Online Sebaran Bidang Tanah ATR/BPN.2020)

Kampung Kota Gandek Puspo mulai berkembang sejak pertengahan tahun 1800 - hingga saat ini, dimana berdasarkan Gambar 4 elemen solid yang muncul sejak dahulu hingga saat ini adalah blok bangunan rumah dan masjid milik Tuan Tasripin di Kampung Kulitan, serta terdapat gudang penyimpanan milik Tuan Tasripin di Kampung Gandekan. Kemudian, diikuti dengan perkembangan kawasan perumahan bagi para pekerja pengkulitan yang berasal dari luar Kota Semarang, para pekerja tersebut dikenal dengan sebutan Kaum Boro. Elemen Void (ruang terbuka) yang tersedia pada tahun 1820 merupakan lahan kosong, kemudian berkembang ditahun 1900 menjadi tempat menjemur kulit dan menjadi lapangan khususnya di Kampung Kulitan dan Kampung Gandekan. Kawasan disekitar kampung tersebut mulai berkembang menjadi kawasan permukiman bagi para pekerja meliputi Kampung Banginggris dan Kampung Pusporagan. Berdasarkan Gambar 3, perkembangan Kampung Kota Gandek Puspo mengarah pada peningkatan blok bangunan yang padat dan tidar teratur mengikuti pola jaringan jalan berbentuk grid dan linear, menyebabkan ruang terbuka yang dulu ada kini telah beralihfungsi menjadi ruang terbangun.

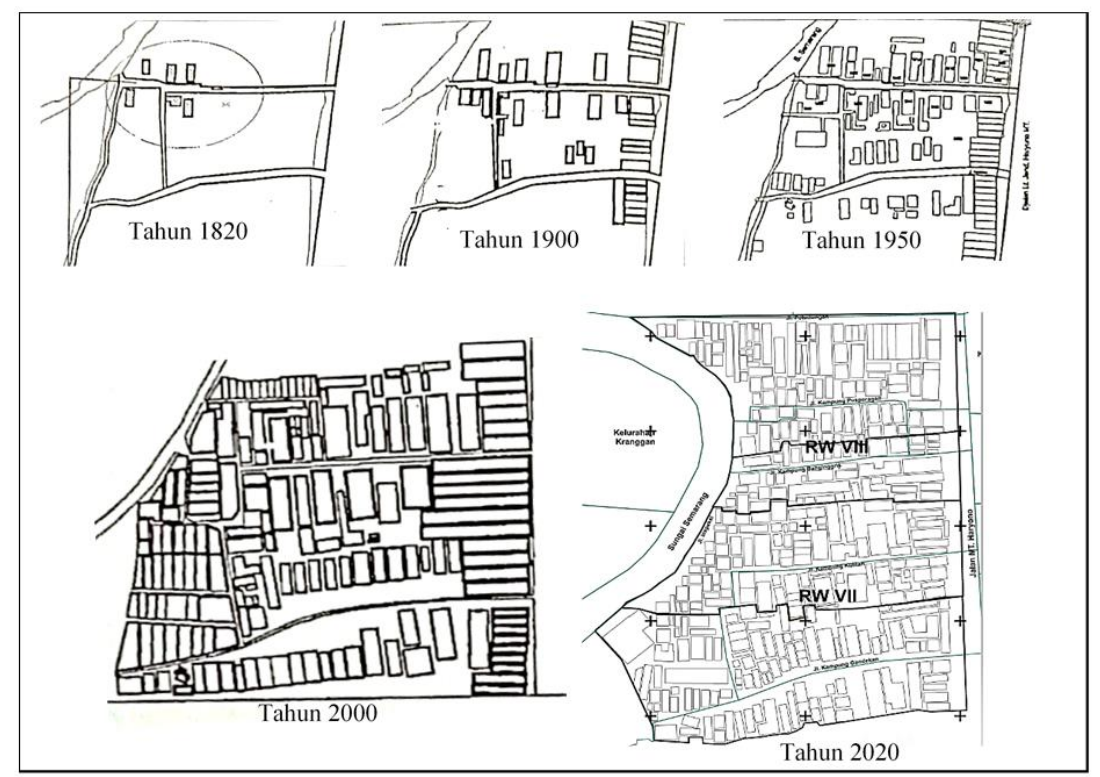

Gambar 3. Kronologi Perkembangan Kampung Kota Gandek Puspo (Nurini,2000;Analisis Penulis, 2020) 
Elemen solid yang paling menonjol di Kampung Gandek Puspo adalah elemen blok tunggal berupa masjid Kampung Kulitan. Sedangkan elemen void yang paling menonjol adalah elemen sistem tertutup yang linear dan elemen sistem tertutup yang sentral (memusat). Sistem linear tertutup di Kampung Kota Gandek Puspo, pada jalan kolektor Kampung Gandekan, Kampung Kulitan, Kampung Banginggris, dan Kampung Pusporagan. Sedangkan, elemen sistem tertutup sentral (memusat) terdapat di salah satu rumah penduduk Kampung Kulitan, ruang terbuka tersebut bersifat private yang dimanfaatkan sebagai ruang sirkulasi udara dan menyejukkan lingkungan rumah.

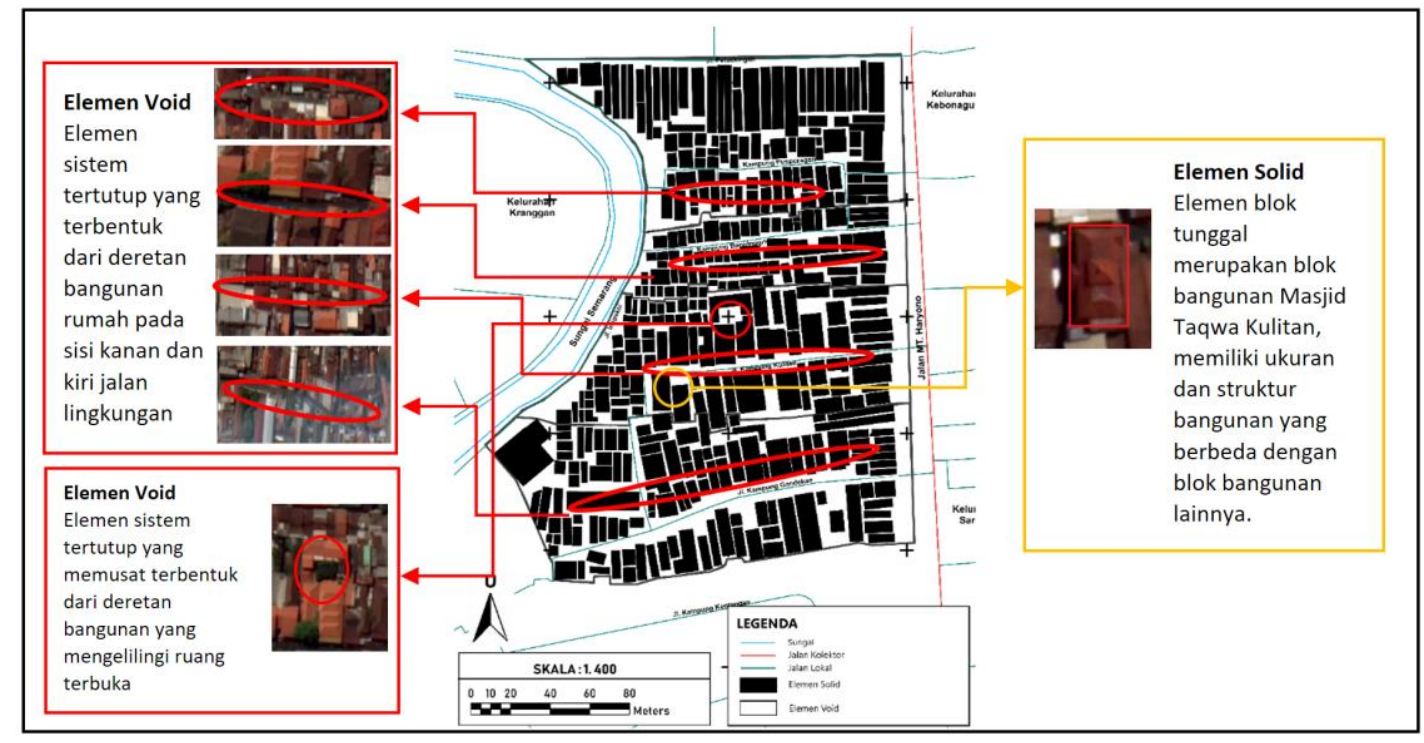

Gambar 4. Peta Analisis Elemen Figure Ground (Analisis Penulis, 2020)

Berdasarkan hasil perbandingan antara kajian literatur dengan kondisi di lokasi penelitian, diketahui bahwa kondisi Kampung Kota Gandek Puspo memiliki kesesuaian bentuk visualisasi lapangan dan bentuk visualisasi google earth yang sama dengan kajian teori figure ground, dimana elemen-elemen figure ground yang ada di lokasi penelitian menjelaskan adanya hubungan antara ruang terbuka (void) dengan blok bangunan (solid).

\subsubsection{Linkage}

Terdapat tiga elemen linkage visual di Kampung Gandek Puspo yang menghubungkan antara dua tempat atau lebih dengan deretan massa bangunn yaitu elemen garis; elemen koridor; dan elemen sisi (Gambar 5). Elemen garis menghubungkan Kampung Banginggris dan Kampung Pusporagan, elemen koridor menghubungkan daerah MT.Haryono dengan Kampung Banginggris dan menghubungkan daerah MT. Haryono dengan Kampung Pusporagan, sedangkan elemen sisi menghubungkan keempat kampung tersebut. Elemen linkage struktural yang menonjol di Kampung Gandek Puspo adalah elemen tambahan (Gambar 3), terjadi penambahan blok bangunan rumah sejak tahun 1800-2020 secara organik (tidak terencana). Penambahan blok bangunan secara organik, membentuk satu kesamaan kawasan yaitu sebagai kawasan permukiman penduduk yang membentuk elemen lingkage kolektif groupform, dimana menghubungkan antar bagian kawasan permukiman Kampung Gandek Puspo. 


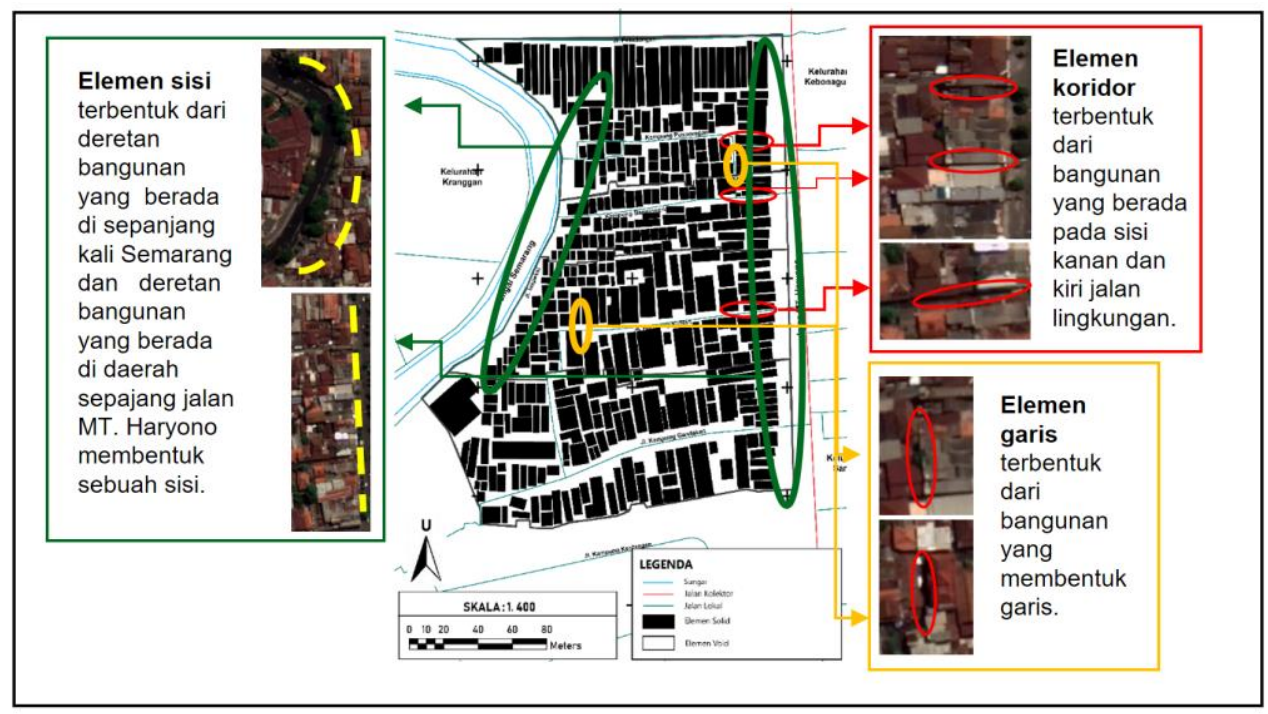

Gambar 5. Peta Analisis Linkage Visual (Analisis Penulis, 2020)

Berdasarkan uraian diatas, dapat dilihat bahwa setiap kawasan saling berhubungan dengan adanya pengaruh elemen-elemen linkage baik secara visual, struktural, maupun kolektif. Hal ini menunjukkan adanya kesesuaian antara kajian teori linkage dengan kondisi di Kampung Kota Gandek Puspo. Dimana, setiap kawasan saling berkaitan antar satu sama lain seperti Kampung Kulitan dengan Kampung Gandekan, Kampung Banginggris dengan Kampung Pusporagan, serta daerah sepanjang jalan MT.Haryono dengan Kampung Kota Gandek Puspo. Keterkaitan yang terbentuk dipengaruhi oleh jaringan jalan, keterkaitan aktivitas, dan kebutuhan masyarakat. Secara visual, kondisi tersebut membentuk elemen garis, sisi dan koridor. Perubahan struktur kawasan dipengaruhi oleh keterkaitan aktivitas masyarakat yang menghubungkan dua/lebih kawasan (aktivitas perdagangan dan jasa dengan aktivitas hunian); serta dapat dipengaruhi oleh peningkatan kebutuhan tempat tinggal.

\subsubsection{Place}

Terdapat dua karakteristik place yang berbeda dari segi aristektural bangunan, yaitu bangunan berarsitektur indis dan bangunan berarsitektur sederhana. Bangunan bergaya indis ditandai dengan beberapa simbol-simbol, ukiran-ukiran yang memadukan budaya Belanda dan Pribumi. Alasan masyarakat masih mempertahankan bangunan bergaya indis, dikarenakan rumah tersebut merupakan rumah peninggalan orang tua terdahulu (turun temurun) dan keterbatasan ekonomi yang menyebabkan beberapa masyarakat masih mempertahankan bentuk aslinya mengkipun dengan kualitas bangunan yang kurang terawat khususnya rumah di Kampung Banginggris dan Kampung Pusporagan, sedangkan bangunan rumah di Kampung Kulitan sebagai besar masih dalam kondisi yang terawat. Adapun ciri khas bangunan indis di Kampung Gandek Puspo diantaranya :

a. Hiasan rumah berbahan logam, meliputi lampu dinding pada salah satu rumah di Kampung Pusporagan dan lampu jalan di Kampung Kulitan.

b. Ukiran pada bagian-bagian bangunan rumah, meliputi ukiran ventilasi bangunan, dan bentuk lisplan rumah yang unik. Dominasi pola ventilasi bangunan berupa sulur tumbuhtumbuhan, dan kumpulan anak panah yang pada bagian ujung anak panah menuju arah pusat (simbol pertahanan diri).

c. Bentuk pintu dan jendela, rumah bergaya indis didominasi dengan tiga pintu rumah dengan dua daun pintu, dan memiliki dua lapisan pintu. Lapisan pertama pintu berbahan kayu jati berukir dan lapisan kedua berupa pintu berbahan kayu yang dilengkapi jendela.

Selain dari segi arsitektural bangunan, makna dan kesan ruang yang ada di Kampung Gandek Puspo dapat dilihat juga dari elemen citra kota. Adapun kelima elemen tersebut sebagai berikut :

a. Elemen path (jalur), menjadi jalur sirkulasi untuk mendukung pergerakan penduduk Kampung Gandek Puspo, meliputi jalan kolektor, jalan lokal, jalan inspeksi. Jalan lingkungan Kampung Kulitan menjadi elemen path yang paling menonjol dan menjadi 
pengingat kawasan sebagai kampung kota bersejarah, hal ini dikarenakan pada sisi kanan dan kiri jalan lingkungan Kampung Kulitan dilengkapi dengan lampu jalan bergaya tempo dulu, lukisan pada dinding jalan, dan bangunan-bangunan rumah bergaya indis.

b. Elemen edge (tepian), digunakan sebagai pembatas sekaligus pemisah antar kawasan di Kampung Gandek Puspo, meliputi Jalan MT.Haryono dan sungai yang menjadi batas kawasan Kampung Gandek Puspo dengan kawasan lainnya.

c. Elemen District (kawasan), terdapat dua kawasan yaitu kawasan perdagangan yang berada dekat jalan MT.Haryono dengan ciri bangunan ruko-ruko berbentuk persegi panjang dan aktivitas dominan perdagangan dan jasa; dan kawasan perumahan masyarakat setempat dengan ciri bangunan rumah berbentuk persegi berukuran besar dan kecil, dengan aktivitas dominan adalah perdagangan, sosial budaya masyarakat.

d. Elemen node (simpul), persimpangan jalan dan jalan inspeksi menjadi titik strategis di Kampung Gandek Puspo. Elemen node yang paling menonjol adalah persimpangan jalan yang menghubungkan Kampung Gandekan dengan Kampung Kulitan, dimana persimpangan jalan tersebut selalu ramai dengan berbagai aktivitas seperti perdagangan, olahraga, interaksi sosial masyarakat, musyawarah, dan lain sebagainnya.

e. Elemen landmark (tangeran), merupakan elemen eksternal yang memiliki bentuk visual menonjol di Kampung Gandek Puspo, meliputi gapuran sebagai penanda pintu masuk kawasan kampung kota, mushola Kampung Gandekan, dan masjid Al Taqwa Kulitan. Elemen node yang paling menonjol adalah mushola Kampung Gandekan, dan masjid Al Taqwa Kulitan, kedua bangunan tersebut memiliki struktur bangunan yang bergaya tempo dulu (lantai mushola berbahan kayu jati).

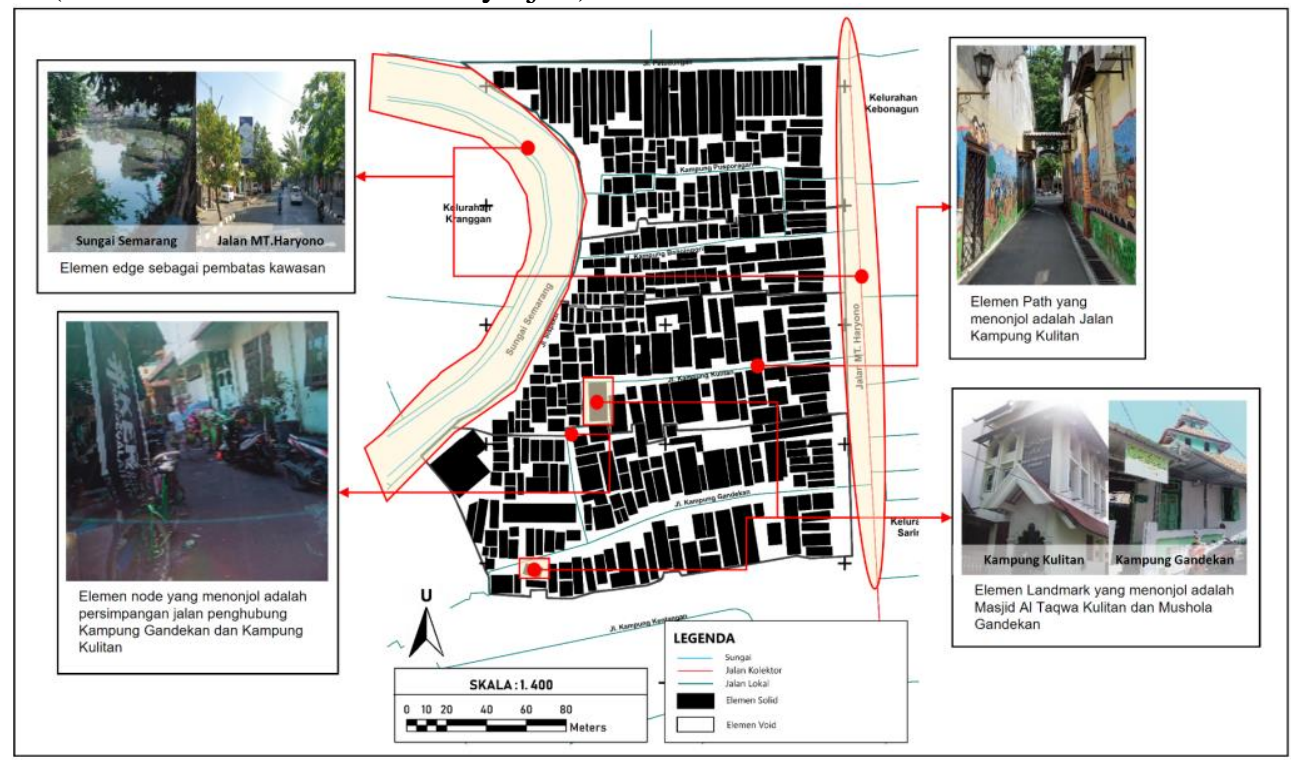

Gambar 6. Peta Analisis Place (Analisis Penulis, 2020)

Berdasarkan hasil analisis, Kampung Kota Gandek Puspo memiliki karakteristik dan makna kawasan yang dapat dilihat dari pendekatan arsitektural (bangunan berarsitektur indis dan bangunan berarsitektur sederhana), dan pendekatan elemen citra kota (path, edge, district, node, dan landmark). Secara keseluruhan Kampung Gandek Puspo memiliki karakteristik kawasan bernuansa tempo dulu yang ditandai dengan bentuk bangunan bergaya indis, street furniture, masjid dan mushola bergaya tempo dulu. Adapun makna dan nilai kawasan berfokus pada nilai historikal kejayaan Tuan Tasripin sebagai tuan tanah di Kota Semarang.

\subsubsection{Hal - Hal yang Mempengaruhi Morfologi Kampung Kota Gandek Puspo}

Terdapat beberapa hal yang dapat mempengaruhi morfologi Kampung Gandek Puspo diantaranya sebagai berikut :

a. Kronologi perkembangan kawasan mempengaruhi bentuk kaveling rumah masyarakat, dimana Tuan Tasripin sebagai tuan tanah membagi menjadi dua yaitu kaveling berukuran besar di Kampung Kulitan sebagai tempat tinggal keluarga Tasripin dan Kampung Gandekan sebagai gudang kulit; kavling berukuran kecil sebagai rumah yang disewakan 
kepada para pekerja/abdi keluarga Tuan Tasripin sebagai tempat tinggal tepatnya di Kampung Banginggris, Kampung Pusporagan, sebagian Kampung Kulitan, dan sebagian Kampung Gandekan.

b. Kebutuhan hunian masyarakat yang beragam, membutuhkan ruang sebagai wadah untuk memenuhi kebutuhan hunian tersebut, meliputi : ruang memasak (dapur), ruang berjualan (toko), ruang mencuci perabotan rumah tangga, ruang mandis (kamar mandi), ruang parkir kendaraan dan lain sebagainnya. Lahan yang terbatas, masyarakat memanfaatakan ruang publik untuk memenuhi kebutuhan hunian, bahkan membangun ruang tambahan untuk memenuhi kebutuhan tersebut.

c. Aktivitas sosial masyarakat yang beragam membutuhkan ruang sebagai wadah aktivitas sosial masyarakat. Kondisi ini menyebabkan terjadinya perubahan fisik bangunan dan perubahan fungsi ruang kawasan. Jalan sebagai akses sehari-hari difungsikan sebagai ruang publik, taman PKK sebagai RTH di Kampung Banginggris direncanakan akan menjadi balai RW setempat.

\subsubsection{Karakteristik Morfologi Kampung Kota Gandek Puspo}

Terdapat dua karakteristik morfologi di Kampung Kota Gandek Puspo yaitu karakteristik I kampung bagian depan (sebagian Kampung Gandekan dan sebagian Kampung Kulitan yang berdekatan dengan jl mt haryono), dan karakteristik II kampung bagian belakang (Kampung Banginggris, Kampung Pusporagan, sebagian Kampung Gandekan, dan sebagian Kampung Kulitan yang berdekatan dengan sungai semarang). Perbedaan kedua karakteristik tersebut meliputi:

a. Kondisi Fisik

- Ukuran kaveling blok bangunan yang besar karena dahulu diperuntukkan sebagai tempat tinggal keluarga Tasripin dan gudang penyimpanan kulit, sedangkan kampung belakang memiliki ukuran kaveling kecil yang diperuntukkan sebagai tempat tinggal pekerja/abdi keluarga Tasripin.

- Rumah penduduk kampung depan telah dilengkapi MCK pribadi, sedangkan kampung belakang belum semua rumah memiliki MCK pribadi, sehingga masyarakat memanfaatkan MCK umum yang berlokasi di Kampung Kulitan dan Kampung Pusporagan.

- Ukuran jaringan jalan kampung depan \pm 3-5 meter, sedangkan kampung belakang memiliki lebar jalan \pm 1 meter.

- Ketersediaan RTH pada kampung depan lebih terbatas dibandingkan kampung belakang yang memiliki deretan pepohanan, di sepanjang sungai Semarang.

- Berdasarkan citra kawasan, kampung bagian depan masih bernuansa tempo dulu khususnya di Kampung Kulitan seperti bangunan rumah bergaya indis yang khas, elemen path berupa jalan lokal Kampung Kulitan yang dilengkapi lukisan dan lampu jalan, mushola Kampung Gandekan, masjid Al Taqwa Kulitan, persimpangan jalan yang khas dengan berbagai aktivitas masyarakat. Sedangkan kampung bagian belakang, nuansa kampung tempo dulu sudah mulai berkurang dan cenderung bernuansa permukiman kampung kota biasa.

- Salah satu cirikhas sebuah kampung kota yaitu adanya lapangan sebagai ruang publik, dahulu di Kampung Gandekan terdapat ruang terbuka cukup luas, bekas lokasi menjemur kulit yg pada periode berikutnya digunakan sebagai lapangan olahraga. Namun saat ini tidak ada lagi karena dipenuhi oleh bangunan rumah.

b. Kondisi Non Fisik

- Dahulu terdapat dua jenis strata sosial masyarakat, Kampung bagian depan sebagai kampung berstrata sosial bangsawan sedangkan kampung bagian belakang sebagai kampung berstrata sosial kalangan menengah kebawah. Namun kondisi tersebut kini sudah tidak terlihat, masyarakat sudah berbaur antar satu sama lain, namun intensitas interaksi sosial masyarakat berbeda. Dimana, kampung bagian depan memiliki intensitas interaksi sosial yang masih kurang khusus Kampung Gandekan, sedangkan kampung bagian belakang memiliki intensitas interaksi sosial yang baik. 


\section{Kesimpulan}

Kampung Kota Gandek Puspo memiliki dua karakteristik morfologi yaitu kampung bagian depan (sebagian Kampung Gandekan dan sebagian Kampung Kulitan yang berdekatan dengan Jl. MT. Haryono), dan kampung bagian belakang (Kampung Banginggris, Kampung Pusporagan, sebagian Kampung Gandekan, dan sebagian Kampung Kulitan yang berdekatan dengan sungai semarang). Perbedaan kedua karakteristik ini dapat terlihat dari karakteristik fisik meliputi ukuran kaveling bangunan dipengaruhi oleh pembagian kavling yang dilakukan oleh Tuan Tasripin. Dimana, dahulu lahan di Kampung Gandek Puspo menjadi milik tuan Tasripin, yang kemudian dibagi-bagi sesuai peruntukan fungsi aktivitasnya, kavling bangunan besar berada di kampung bagian depan yang diperuntukan sebagai gudang dan tempat tinggal keluarga Tuan Tasripin. Sedangkan kavling berukuran kecil disewakan kepada para pekerja/abdi tuan Tasripin sebagai tempat tinggal yang berada pada kawasan kampung bagian belakang. Selain itu, perbedana lainnya dapat dilihat dari kelengkapan sanitasi disetiap rumah (MCK pribadi), kondisi lingkungan perumahan, ukuran lebar jalan yang lebih lebar, bangunan rumah berarsitektur indis, jenis bangunan rumah, jarak antar bangunan, ketersediaan ruang terbuka hijau. Serta, kondisi non fisik berupa intensitas interaksi antar masyarakat.

Berdasarkan karakteristik I kampung bagian depan, menjadi perhatian pemerintah setempat bersama masyarakat untuk berupaya mempertahankan bangunan bersejarah yang menjadi identitas dan ciri kawasan, dengan melakukan konservasi dan pemugaran pada bangunan bersejarah seperti pada bangunan berarsitektur Indis, masjid Al Taqwa Kulitan, dan Mushola Kampung Gandekan. Mengingat banyaknya perubahan yang telah terjadi sejak dahulu hingga saat ini, mulai mengubah bentuk dan fungsi morfologi kawasan, dan ketika identitas dan ciri dari Kampung Kota Gandek Puspo hilang maka akan menghilangkan rasa ketidakpedulian terhadap nilai sejarah dan proses perkembangan kawasan, serta menghilangkan salah satu destinasi historikal di Kota Semarang, dengan adanya perencanaan dan pengembangan kawasan yang sesuai dengan karakteristik morfologi kawasan dapat berkontribusi dibidang pariwisata bersejarah Kota Semarang. Berdasarkan karakteristik II kampung bagian belakang, menjadi perhatian pemerintah setempat bersama masyarakat untuk melakukan penataan kawasan, khususnya di sepanjang sungai Semarang dan melakukan pemugaran kembali pada beberapa bangunan rumah bergaya indis yang berjenis non permanen. Penataan kawasan di sepanjang sungai Semarang yang dimaksud berupa, pembuatan RTH berupa taman green belt untuk menambah nilai estetika kawasan, hal ini dikarenakan kondisi sungai Semarang saat ini penuh dengan endapan sampah; serta pembuatan pagar disepanjang sungai Semarang sebagai bentuk keamanan dan keselamatan masyarakat, mengingat saat ini pada pinggir sungai Semarang tidak terdapat pagar pelindung. Hal ini bertujuan untuk, meningkatkan nilai estetika kawasan, meningkatkan kualitas hidup masyarakat, dan memenuhi kebutuhan ruang publik bagi masyarakat sebagai ciri dari kawasan Kampung Kota yaitu adanya ruang publik sebagai wadah untuk berkumpul dan berinteraksi. Sehingga, kajian karakteristik morfologi Kampung Kota Gandek Puspo sudah seharusnya menjadi pertimbangan dalam perencanaan dan pembangunan kawasan untuk menciptakan kawasan yang berkelanjutan dan sejahtera.

\section{Referensi}

Agirbas, A., \& Ardaman, E. (2015). A Morphological Comparison of Urban Tissues of Trani and Galata. Journal of Architecture and Urbanism, 39(4), 232-247. https://doi.org/10.3846/20297955.2015.1113899

Ariga, T. (2005). Morphology, Sustainable Evolution of Inner-urban Neighborhoods in San Francisco. Journal of Asian Architecture and Building Engineering, 4(1), 143-150. https://doi.org/10.3130/jaabe.4.143

Funo, S., Yamamoto, N., \& Silas, J. (2002). Typology of Kampung Houses and Their Transformation Process--A Study on Urban Tissues of an Indonesian City. Journal of Asian Architecture and Building Engineering, 1(2), 193-200. https://doi.org/10.3130/jaabe.1.2_193

Kurniasari, P., Gabe, R. T., \& Adianto, J. (2019). Spatial Extension As A Housing Strategy In Kampung Kota: A Case Study From Kampung Kingkit, Central Jakarta. IOP Conference Series: Materials Science and Engineering, 523(1). https://doi.org/10.1088/1757899X/523/1/012049 
Lynch, K. (1960). The Image of the City. The Joint Center For Urban Studies. https://doi.org/10.1093/acprof:oso/9780199913879.003.0003

Nurini. (2002). Kajian Perkembangan Morfologi Kampung Gandek Puspo-Semarang (Priode 1800 - 2000).

Soekiman, D. (2014). Kebudayaan Indis Dari Zaman Kompeni Sampai Revolusi (First). Komunitas Bambu.

Sugiyono. (2015). Metode Penelitian Kuantitatif, Kulaitatif, dan R\&D. ALFABETA.

Zahnd, M. (1999). Perancangan Kota Secara Terpadu Teori Perancangan Kota dan Penerapannya. Kanisius dan Soegijapranata University Press. 